\title{
Quality of Heliconia psittacorum seedlings grown on different substrates ${ }^{(1)}$
}

\author{
RAIMUNDO LUIZ LAURINHO DOS SANTOS(2); JOSÉ ANTONIO SARAIVA GROSSI(2); \\ ROGÉRIO GOMES PÊGO(2) and JOSÉ GERALDO BARBOSA(2)*
}

\begin{abstract}
The production of good seedlings depends on the quality of the matrix and propagation techniques used. In choosing a substrate should be particularly observed physical and chemical characteristics. The objective of this study was to assess the development and vigor of heliconia seedlings from Heliconia psittacorum species, grown on different substrates and mixtures. The materials that form the treatments were: burnt rice husk (RHB), vermiculite (VC), sugarcane waste burnt (SWB), subsoil (S), chicken bedding (CB), cattle manure (CM), earthworm humus (EH), coconut husk powder (CSP) and Horticultural Plantmax (HP). The treatments chosen were: $1(2 / 3 \mathrm{CM}+1 / 3 \mathrm{CSP}), 2(2 / 3 \mathrm{CM}+1 / 3 \mathrm{RHB}), 3(2 / 3 \mathrm{CB}+1 / 3 \mathrm{SWB}), 4(\mathrm{CSP}), 5(1 / 2 \mathrm{VC}+1 / 2 \mathrm{SWB}), 6(2 / 3 \mathrm{~S}+1 / 3 \mathrm{CB}), 7(1 / 3 \mathrm{CM}+$ $2 / 3 \mathrm{SWB}), 8(2 / 3 \mathrm{CM}+1 / 3 \mathrm{SWB}), 9(2 / 3 \mathrm{CB}+1 / 3 \mathrm{RHB}), 10(1 / 3 \mathrm{CM}+2 / 3 \mathrm{RHB}), 11(1 / 3 \mathrm{CB}+2 / 3 \mathrm{SWB}), 12(2 / 3 \mathrm{CB}+1 / 3 \mathrm{CSP}), 13(2 / 3 \mathrm{EH}+1 / 3 \mathrm{CSP})$, $14(2 / 3 \mathrm{EH}+1 / 3 \mathrm{SWB}), 15(1 / 3 \mathrm{CB}+2 / 3 \mathrm{RHB}), 16(1 / 3 \mathrm{EH}+2 / 3 \mathrm{SWB}), 17(2 / 3 \mathrm{EH}+1 / 3 \mathrm{RHB}), 18(1 / 2 \mathrm{VC}+1 / 2 \mathrm{RHB}), 19(\mathrm{~S}), 20(2 / 3 \mathrm{~S}+1 / 3 \mathrm{CM})$, $21(2 / 3 \mathrm{~S}+1 / 3 \mathrm{EH}), 22(\mathrm{EH}), 23(\mathrm{HP}), 24(1 / 3 \mathrm{EH}+2 / 3 \mathrm{RHB})$. Samples of all treatment compositions were taken and carried out chemical and physical analysis. A set of ten treatments $(1,2,5,7,8,10,14,16,20$ and 22) basically consisting of CM EH, RHB, CSP and SWB produced the best seedlings and treatment with $\mathrm{CB}$ as a main component or not produced the worst seedlings due to high electrical conductivity.
\end{abstract}

Keywords: propagation, ornamental plants, electrical conductivity, alternative substrate, tropical flowers.

\section{RESUMO}

Qualidade de mudas de Heliconia psittacorum crescidas em diferentes substratos

A produção das mudas depende da qualidade da matriz e das técnicas de propagação utilizadas. Na escolha do substrato deve ser particularmente observado características físicas e químicas. O objetivo deste estudo foi avaliar o desenvolvimento e o vigor de mudas de helicônias de espécies Heliconia psittacorum, cultivadas em diferentes substratos e misturas. Os materiais usados para compor os tratamentos foram: casca de arroz queimado (RHB), vermiculita (VC), bagaço de cana carbonizada (SWB), subsolo (S), cama de frango (CB), esterco bovino (CM), húmus de minhoca (EH), pó de casca de coco (CSP) e Plantmax para horticultura. Os tratamentos escolhidos foram: $1(2 / 3 \mathrm{CM}+1 / 3 \mathrm{CSP}), 2(2 / 3 \mathrm{CM}+1 / 3 \mathrm{RHB}), 3(2 / 3 \mathrm{CB}+1 / 3 \mathrm{SWB}), 4$ (CSP), $5(1 / 2 \mathrm{VC}+1 / 2 \mathrm{SWB}), 6(2 / 3 \mathrm{~S}+1 / 3$ $\mathrm{CB}), 7(1 / 3 \mathrm{CM}+2 / 3 \mathrm{SWB}), 8(2 / 3 \mathrm{CM}+1 / 3 \mathrm{SWB}), 9(2 / 3 \mathrm{CB}+1 / 3 \mathrm{RHB}), 10(1 / 3 \mathrm{CM}+2 / 3 \mathrm{RHB}), 11(1 / 3 \mathrm{CB}+2 / 3 \mathrm{SWB}), 12(2 / 3 \mathrm{CB}+1 / 3 \mathrm{CSP}), 13$ $(2 / 3 \mathrm{EH}+1 / 3 \mathrm{CSP}), 14(2 / 3 \mathrm{EH}+1 / 3 \mathrm{SWB}), 15(1 / 3 \mathrm{CB}+2 / 3 \mathrm{RHB}), 16(1 / 3 \mathrm{EH}+2 / 3 \mathrm{SWB}), 17(2 / 3 \mathrm{EH}+1 / 3 \mathrm{RHB}), 18(1 / 2 \mathrm{VC}+1 / 2 \mathrm{RHB}), 19$ (S), 20 $(2 / 3 \mathrm{~S}+1 / 3 \mathrm{CM}), 21(2 / 3 \mathrm{~S}+1 / 3 \mathrm{EH}), 22(\mathrm{EH}), 23(\mathrm{HP}), 24(1 / 3 \mathrm{EH}+2 / 3 \mathrm{RHB})$. As amostras de todas as composições de tratamento foram tomadas e realizadas análises químicas e físicas. Um conjunto de dez tratamentos (1, 2, 5, 7, 8, 10, 14, 16, 20 e 22), basicamente, composto de CM EH, RHB, CSP e SWB produzem as mudas de melhor qualidade e tratamento com CB, como um componente principal ou não, produziu as piores mudas devido à alta condutividade elétrica.

Palavras-chave: Propagação, plantas ornamentais, condutividade elétrica, substratos alternativos, flores tropicais.

\section{INTRODUCTION}

The heliconias are used as gardens' plants and as cut flowers, adapting perfectly for use in pots or composing floral arrangements (CASTRO et al., 2007), with increasing participation in the landscaping and tropical floriculture. The ideal substrate for the seedlings production is one that has uniformity in its composition, low density, good absorption capacity and water retention and supply of nutrients required to the plants, good aeration, sufficient drainage and relief of pests, pathogenic organisms and undesirable plant seed. In addition to that, it should provide facility to be worked at any time, be abundant, economically viable and form soil blocks that do not disintegrate during transport and in the unpacking that involve the seedling (WENDLING and GATTO, 2002).

Most research papers related to substrates, both for its characterization (physical or physico-chemical) as regards the efficiency as culture medium has been directed to the production of ornamental plants, forestry and fruit (MENEZES JUNIOR et al., 1998).

According Teixeira et al. (2000), the animal manure, due to its wide availability and importance on growth and increasing production of plants are considered important organic fertilizers. The cattle manure and chicken bedding are organic fertilizers most used in the region, mainly in the production of vegetables and fruit seedlings.

\footnotetext{
(1) Received in 25/01/2013 and approved in 19/10/2015

(1) Universidade Federal de Viçosa (UFV), Departamento de Fitotecnia, Viçosa-MG, Brazil. * Corresponding author: jgrossi@ufv.br
} 
In addition, the burnt rice husk, sugarcane waste, fiber and coconut powder are widely used in the ornamental seedlings production, particularly in the spread.

Experiment conducted by Bezerra et al. (2001), on the rooting of chrysanthemum cuttings in burnt rice husk (RHB), mature coconut husk powder and green coconut husk powder, showed superiority of RHB in relation to the green coconut husk powder, with no difference between the RHB and mature coconut husk powder. These same authors observed more intense aggregation of coconut husk powder in relation to the RHB along the roots, providing greater substrate stability.

The sugarcane waste burnt has been used as a substrate for rooting of ornamental plants. The sugarcane waste has also been recommended for growing orchids for enabling high water retention capacity and also sweet alison (Alyssum maritimum) as potted plant because due to have large fibrous particles and prolonged stability (MEURER et al., 2008; SPIER et al., 2009).

According Rosa et al. (2001), the substrates obtained from mature fruits of the coconut prove to be the best growth media for plant production. The mature coconut powder is a plant material 100\% natural, renewable, very light like the Sphagnum peat, found in northern Europe and North America. Currently, the dry coconut powder is being indicated as an agricultural substrate, both have advantageous physical structure, which provides high porosity and high moisture retention, such as biodegradable material.

The increasing use of organic compounds as substrate during this stage (seedlings production) reflects the need for sustainable agricultural practices that minimize environmental impact. However, it is important to assess, for each crop, the substrates appropriate to their development (SCEHITZ et al., 2002).

Nowadays the substrates available in the domestic market are indistinctly recommended for a large number of species whose formulations and characteristics are virtually unknown and they have shown regular performance as a culture medium. Thus, the objective of this study was to investigate the development and vigor of heliconia seedlings from the $H$. psittacorum species, grown on different substrates and mixtures.

\section{MATERIAL AND METHODS}

The species of heliconia proposal for this work was Heliconia psittacorum, cultivar 'Andromeda' for being one of indicated by specialists in ornamental plants of EPAMIG (LUZ et al., 2005) for planting in the state. The experiment was developed under $50 \%$ shading nets.

The heliconia rhizomes were obtained in the floriculture sector at the Department of Plant Science of UFV, which were cleaned and disinfected with hypochlorite solution $(0.5 \%)$. The average length of the rhizomes was $15 \mathrm{~cm}$ plus another piece of pseudostem
$10 \mathrm{~cm}$. Once cleaned and disinfected the rhizomes were placed to root on substrates composed of different materials selected according to the availability and cost.

The materials that form the treatments were: burnt rice husk (RHB), vermiculite (VC), sugarcane waste burnt (SWB), subsoil (S), chicken bedding (CB), cattle manure $(\mathrm{CM})$, earthworm humus $(\mathrm{EH})$, coconut husk powder (CSP) and horticultural Plantmax, as follows the treatments and their mixtures:

$\mathrm{T} 1-2 / 3 \mathrm{CM}+1 / 3 \mathrm{CSP}-(2 / 3)$ cattle manure $+(1 / 3)$ coconut husk powder;

$\mathrm{T} 2-2 / 3 \mathrm{CM}+1 / 3 \mathrm{RHB}-(2 / 3)$ cattle manure $+(1 / 3)$ burnt rice husk;

T3 $-2 / 3 \mathrm{CB}+1 / 3$ SWB $-(2 / 3)$ chicken bedding $+(1 / 3)$ sugarcane waste burnt;

T4 - CSP - coconut husk powder;

T5 - 1/2 VC+ $1 / 2 \mathrm{SWB}-(1 / 2)$ vermiculite $+(1 / 2)$ sugarcane waste burnt;

T6 $-2 / 3 \mathrm{~S}+1 / 3 \mathrm{CB}-(2 / 3)$ subsoil $+(1 / 3)$ chicken bedding;

$\mathrm{T} 7-1 / 3 \mathrm{CM}+2 / 3 \mathrm{SWB}-(1 / 3)$ cattle manure $+(2 / 3)$ sugarcane waste burnt;

$\mathrm{T} 8-2 / 3 \mathrm{CM}+1 / 3 \mathrm{SWB}-(2 / 3)$ cattle manure $+(1 / 3)$ sugarcane waste burnt;

T9 $-2 / 3 \mathrm{CB}+1 / 3 \mathrm{RHB}-(2 / 3)$ chicken bedding $+(1 / 3)$ burnt rice husk;

T10- $1 / 3 \mathrm{CM}+2 / 3 \mathrm{RHB}-(1 / 3)$ cattle manure $+(2 / 3)$ burnt rice husk;

$\mathrm{T} 11-1 / 3 \mathrm{CB}+2 / 3 \mathrm{SWB}-(1 / 3)$ chicken bedding $+(2 / 3)$ sugarcane waste burnt;

T12 - $2 / 3 \mathrm{CB}+1 / 3 \mathrm{CSP}-(2 / 3)$ chicken bedding $+(1 / 3)$ coconut husk powder.

T13 - $2 / 3 \mathrm{EH}+1 / 3 \mathrm{CSP}-(2 / 3)$ earthworm humus $+(1 / 3)$ coconut husk powder;

$\mathrm{T} 14-2 / 3 \mathrm{EH}+1 / 3 \mathrm{SWB}-(2 / 3)$ earthworm humus $+(1 / 3)$ sugarcane waste burnt;

T15 - 1/3CB $+2 / 3$ RHB $-(1 / 3)$ chicken bedding + (2/3) burnt rice husk;

$\mathrm{T} 16-1 / 3 \mathrm{EH}+2 / 3 \mathrm{SWB}-(1 / 3)$ earthworm humus $+(2 / 3)$ sugarcane waste burnt;

T17 $-2 / 3 \mathrm{EH}+1 / 3 \mathrm{RHB}-(2 / 3)$ earthworm humus $+(1 / 3)$ burnt rice husk;

$\mathrm{T} 18-1 / 2 \mathrm{VC}+1 / 2 \mathrm{RHB}-(1 / 2)$ vermiculite $+(1 / 2)$ burnt rice husk;

T19 - S - subsoil;

$\mathrm{T} 20-2 / 3 \mathrm{~S}+1 / 3 \mathrm{CM}-(2 / 3)$ subsoil $+(1 / 3)$ cattle manure;

$\mathrm{T} 21-2 / 3 \mathrm{~S}+1 / 3 \mathrm{EH}-(2 / 3)$ subsoil $+(1 / 3)$ earthworm humus; T22 - EH - earthworm humus;

T23 - HP - Horticultural Plantmax;

$\mathrm{T} 24-1 / 3 \mathrm{EH}+2 / 3 \mathrm{RHB}-(1 / 3)$ earthworm humus $+(2 / 3)$ burnt rice husk.

The materials were mixed and placed in black plastic pots of $5 \mathrm{~kg}$. Sample was taken of each substrate for determination of its main characteristics, as shown in Tables 1, 2, 3 and 4 . 
Table 1 - Electrical conductivity, density and porosity of the substrates used in the production of Heliconia psittacorum seedlings.

\begin{tabular}{|c|c|c|c|c|c|}
\hline \multirow{2}{*}{ Number } & \multirow{2}{*}{ Treatments } & \multirow{2}{*}{$\mathrm{EC}(\mathrm{ds} / \mathrm{m})$} & \multicolumn{2}{|c|}{ Densities $\left(\mathrm{g} / \mathrm{cm}^{3}\right)$} & \multirow{2}{*}{ Porosity total(\%) } \\
\hline & & & apparent & particle & \\
\hline 1 & $2 / 3 \mathrm{CM}+1 / 3 \mathrm{CSP}$ & 2.07 & 0.49 & 3.02 & 83.77 \\
\hline 2 & $2 / 3 \mathrm{CM}+1 / 3 \mathrm{RHB}$ & 2.61 & 0.45 & 2.71 & 83.46 \\
\hline 3 & $2 / 3 \mathrm{CB}+1 / 3 \mathrm{SWB}$ & 4.93 & 0.21 & 1.89 & 88.89 \\
\hline 4 & CSP & 0.72 & 0.13 & 1.67 & 92.22 \\
\hline 5 & $1 / 2 \mathrm{VC}+1 / 2 \mathrm{SWB}$ & 1.11 & 0.35 & 3.48 & 89.94 \\
\hline 6 & $2 / 3 \mathrm{~S}+1 / 3 \mathrm{CB}$ & 3.04 & 0.70 & 3.28 & 78.66 \\
\hline 7 & $1 / 3 \mathrm{CM}+2 / 3 \mathrm{SWB}$ & 1.58 & 0.31 & 3.37 & 90.80 \\
\hline 8 & $2 / 3 \mathrm{CM}+1 / 3 \mathrm{SWB}$ & 3.57 & 0.37 & 3.76 & 90.16 \\
\hline 9 & $2 / 3 \mathrm{CB}+1 / 3 \mathrm{RHB}$ & 4.89 & 0.22 & 1.82 & 87.91 \\
\hline 10 & $1 / 3 \mathrm{CM}+2 / 3 \mathrm{RHB}$ & 1.81 & 0.31 & 2.87 & 89.20 \\
\hline 11 & $1 / 3 \mathrm{CB}+2 / 3 \mathrm{SWB}$ & 4.29 & 0.20 & 5.55 & 96.40 \\
\hline 12 & $2 / 3 \mathrm{CB}+1 / 3 \mathrm{CSP}$ & 4.96 & 0.24 & 2.95 & 91.86 \\
\hline 13 & $2 / 3 \mathrm{EH}+1 / 3 \mathrm{CSP}$ & 1.80 & 0.39 & 3.76 & 89.63 \\
\hline 14 & $2 / 3 \mathrm{EH}+1 / 3 \mathrm{SWB}$ & 1.10 & 0.44 & 2.59 & 83.01 \\
\hline 15 & $1 / 3 \mathrm{CB}+2 / 3 \mathrm{RHB}$ & 3.84 & 0.21 & 2.25 & 90.67 \\
\hline 16 & $1 / 3 \mathrm{EH}+2 / 3 \mathrm{SWB}$ & 0.82 & 0.23 & 2.00 & 88.50 \\
\hline 17 & $2 / 3 \mathrm{EH}+1 / 3 \mathrm{RHB}$ & 1.23 & 0.38 & 2.38 & 84.03 \\
\hline 18 & $1 / 2 \mathrm{VC}+1 / 2 \mathrm{RHB}$ & 1.52 & 0.35 & 2.06 & 83.01 \\
\hline 19 & $\mathrm{~S}$ & 0.09 & 1.26 & 4.76 & 73.53 \\
\hline 20 & $2 / 3 \mathrm{~S}+1 / 3 \mathrm{CM}$ & 1.64 & 0.90 & 3.24 & 72.22 \\
\hline 21 & $2 / 3 S+1 / 3 E H$ & 0.99 & 1.31 & 3.91 & 66.45 \\
\hline 22 & EH & 1.83 & 0.44 & 1.93 & 77.20 \\
\hline 23 & HP & 1.16 & 0.53 & 2.73 & 80.59 \\
\hline 24 & $1 / 3 \mathrm{EH}+2 / 3 \mathrm{RHB}$ & 1.04 & 0.28 & 2.44 & 88.52 \\
\hline
\end{tabular}

$\mathrm{CM}=$ cattle manure; $\mathrm{CSP}=$ coconut husk powder; $\mathrm{VC}=$ vermiculite; $\mathrm{CB}=$ chicken bedding; $\mathrm{SWB}=$ sugarcane waste burnt; RHB = burnt rice husk; HP = Horticultural Plantmax; EH = earthworm humus; $\mathrm{S}=$ subsoil. 
Table 2: Water retention of the substrates used in the production of Heliconia psittacorum seedlings.

\begin{tabular}{|c|c|c|c|c|c|c|}
\hline \multirow{3}{*}{ Number } & \multirow{3}{*}{ Treatments * } & \multicolumn{5}{|c|}{ Potential kPa } \\
\hline & & -6 & -10 & -100 & -500 & -1.500 \\
\hline & & \multicolumn{5}{|c|}{ - } \\
\hline 1 & $2 / 3 \mathrm{CM}+1 / 3 \mathrm{CSP}$ & 1.838 & 1.705 & 1.669 & 1.625 & 1.367 \\
\hline 2 & $2 / 3 \mathrm{CM}+1 / 3 \mathrm{RHB}$ & 1.394 & 1.239 & 1.202 & 1.159 & 1.079 \\
\hline 3 & $2 / 3 \mathrm{CB}+1 / 3 \mathrm{SWB}$ & 2.225 & 2.351 & 2.264 & 2.159 & 1.822 \\
\hline 4 & CSP & 4.220 & 3.990 & 3.883 & 3.753 & 2.353 \\
\hline 5 & $1 / 2 \mathrm{VC}+1 / 2 \mathrm{SWB}$ & 1.840 & 1.718 & 1.675 & 1.624 & 1.462 \\
\hline 6 & $2 / 3 \mathrm{~S}+1 / 3 \mathrm{CB}$ & 0.497 & 0.487 & 0.471 & 0.451 & 0.416 \\
\hline 7 & $1 / 3 \mathrm{CM}+2 / 3 \mathrm{SWB}$ & 1.754 & 1.525 & 1.478 & 1.421 & 1.258 \\
\hline 8 & $2 / 3 \mathrm{CM}+1 / 3 \mathrm{SWB}$ & 2.034 & 1.677 & 1.618 & 1.488 & 1.339 \\
\hline 9 & $2 / 3 \mathrm{CB}+1 / 3 \mathrm{RHB}$ & 1.690 & 2.053 & 1.990 & 1.914 & 1.456 \\
\hline 10 & $1 / 3 \mathrm{CM}+2 / 3 \mathrm{RHB}$ & 1.057 & 0.931 & 0.890 & 0.840 & 0.790 \\
\hline 11 & $1 / 3 \mathrm{CB}+2 / 3 \mathrm{SWB}$ & 2.199 & 2.555 & 2.477 & 2.384 & 1.756 \\
\hline 12 & $2 / 3 \mathrm{CB}+1 / 3 \mathrm{CSP}$ & 2.541 & 2.734 & 2.663 & 2.578 & 1.854 \\
\hline 13 & $2 / 3 \mathrm{EH}+1 / 3 \mathrm{CSP}$ & 1.844 & 1.719 & 1.667 & 1.604 & 1.320 \\
\hline 14 & $2 / 3 \mathrm{EH}+1 / 3 \mathrm{SWB}$ & 1.632 & 1.524 & 1.471 & 1.407 & 1.184 \\
\hline 15 & $1 / 3 \mathrm{CB}+2 / 3 \mathrm{RHB}$ & 1.297 & 1.426 & 1.355 & 1.270 & 1.010 \\
\hline 16 & $1 / 3 \mathrm{EH}+2 / 3 \mathrm{SWB}$ & 2.393 & 2.205 & 2.142 & 2.067 & 1.524 \\
\hline 17 & $2 / 3 \mathrm{EH}+1 / 3 \mathrm{RHB}$ & 1.202 & 1.057 & 1.022 & 0.980 & 0.927 \\
\hline 18 & $1 / 2 \mathrm{VC}+1 / 2 \mathrm{RHB}$ & 1.208 & 1.100 & 1.060 & 1.012 & 0.925 \\
\hline 19 & $\mathrm{~S}$ & 0.333 & 0.291 & 0.281 & 0.269 & 0.258 \\
\hline 20 & $2 / 3 \mathrm{~S}+1 / 3 \mathrm{CM}$ & 0.521 & 0.501 & 0.483 & 0.463 & 0.397 \\
\hline 21 & $2 / 3 \mathrm{~S}+1 / 3 \mathrm{EH}$ & 0.486 & 0.452 & 0.436 & 0.416 & 0.378 \\
\hline 22 & $\mathrm{EH}$ & 1.744 & 1.685 & 1.646 & 1.600 & 1.383 \\
\hline 23 & HP & 0.987 & 0.917 & 0.893 & 0.863 & 0.743 \\
\hline 24 & $1 / 3 \mathrm{EH}+2 / 3 \mathrm{RHB}$ & 1.149 & 1.052 & 0.999 & 0.936 & 0.785 \\
\hline
\end{tabular}

Soil Physics Laboratory UFV - 28/10/2009.

Table 3: Chemical analysis of treatment with subsoil used to produce of Heliconia psittacorum seedlings.

\begin{tabular}{|c|c|c|c|c|c|c|c|c|c|c|c|c|c|}
\hline \multirow{2}{*}{ Ident. } & \multicolumn{2}{|l|}{$\mathrm{pH}$} & $\mathrm{P}$ & & $\mathrm{K}$ & $\mathrm{Na}$ & \multicolumn{2}{|c|}{$\mathrm{Ca}^{2+}$} & $\mathrm{Mg}^{2+}$ & & $\mathrm{Al}^{3+}$ & \multicolumn{2}{|c|}{$\mathrm{H}+\mathrm{al}$} \\
\hline & \multicolumn{2}{|c|}{$\mathrm{H}_{2} \mathrm{O}$} & \multicolumn{4}{|c|}{---------------mg/dm³'----------- } & \multicolumn{7}{|c|}{ 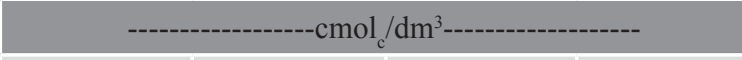 } \\
\hline S & \multicolumn{2}{|c|}{5,1} & 3,4 & & 47 & 3 & \multicolumn{2}{|c|}{1,1} & 0,5 & & 0,4 & \multicolumn{2}{|c|}{3,96} \\
\hline SB & CECE & CEC & V & $\mathrm{m}$ & ISNa & $\mathrm{OM}$ & P-rem & $\mathrm{Zn}$ & $\mathrm{Fe}$ & $\mathrm{Mn}$ & $\mathrm{Cu}$ & B & S \\
\hline \multicolumn{3}{|c|}{$-\mathrm{Cmol}_{\mathrm{c}} / \mathrm{dm}^{3} \mathrm{----}$} & \multicolumn{3}{|c|}{ - - n } & $\mathrm{Dag} / \mathrm{Kg}$ & $\mathrm{Mg} / \mathrm{L}$ & \multicolumn{6}{|c|}{ 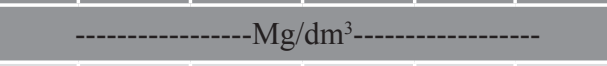 } \\
\hline 1,72 & 2,12 & 5,68 & 30 & 19 & - & 1,2 & - & 2,2 & 68,5 & 26,1 & 2,3 & 0,2 & 51,7 \\
\hline
\end{tabular}

$\mathrm{pH}$ in water, $\mathrm{KCl}$ and $\mathrm{CaCl}_{2}-$ Ratio $1: 2,5$

$\mathrm{P}-\mathrm{Na}-\mathrm{K}-\mathrm{Fe}-\mathrm{Zn}-\mathrm{Cu}-$ Extractor Mehlic 1

$\mathrm{Ca}-\mathrm{Mg}-\mathrm{Al}-$ Extractor $\mathrm{KCl}-1 \mathrm{~mol} /$

$\mathrm{H}+\mathrm{Al}-$ Extractor Calcium Acetate $0,5 \mathrm{~mol} / \mathrm{L}-\mathrm{pH} 70$

B - Extractor Hot water

$\mathrm{S}$ - Extractor - Monocalcium phosphate in acetic acid

$\mathrm{SB}=$ exchangeable sum basis

$\mathrm{P}-$ rem $=$ Remaining phosphorus
CECE - Cation Exchange Capacity effective

$\mathrm{CEC}$ - Cation Exchange Capacity to $\mathrm{pH} 7,0$

$\mathrm{V}=$ Basis saturation index

$\mathrm{m}=$ Aluminium saturation index

ISNa - Sodium Saturation Index

Org. Mat. $(\mathrm{OM})=$ Org. C. x 1.724

(Walkley-Black) 
Table 4: Chemical analysis of substrates used in the production of Heliconia psittacorum seedlings.

\begin{tabular}{|c|c|c|c|c|c|c|c|c|}
\hline \multirow{2}{*}{ Ident. } & $\mathrm{N}$ & $P$ & $\mathrm{~K}$ & $\mathrm{Ca}$ & $\mathrm{Mg}$ & S & $\mathrm{CO}$ & \multirow{2}{*}{$\mathrm{C} / \mathrm{N}$} \\
\hline & \multicolumn{7}{|c|}{ 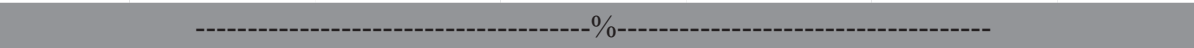 } & \\
\hline $\mathrm{CB}$ & 2.13 & 1.49 & 3.28 & 4.27 & 0.67 & 0.78 & 28.86 & 13.54 \\
\hline $\mathrm{HP}_{\mathrm{HT}}$ & 0.87 & 0.22 & 0.16 & 1.53 & 1.69 & 0.51 & 16.38 & 18.82 \\
\hline RHB & 0.59 & 0.15 & 0.40 & 0.52 & 0.09 & 0.09 & 7.80 & 13.22 \\
\hline $\mathrm{VC}$ & 0.56 & 0.13 & 0.80 & 1.62 & 17.28 & 0.67 & 0.78 & 1.39 \\
\hline SWB & 0.48 & 0.16 & 0.40 & 4.55 & 0.81 & 0.32 & 5.14 & 10.70 \\
\hline $\mathrm{EH}$ & 1.88 & 0.63 & 1.04 & 2.17 & 0.94 & 0.69 & 16.84 & 8.95 \\
\hline CSP & 0.50 & 0.10 & 1.04 & 1.35 & 0.45 & 0.34 & 33.54 & 67.08 \\
\hline $\mathrm{CM}$ & 1.82 & 0.47 & 2.08 & 1.53 & 0.75 & 0.62 & 23.71 & 13.02 \\
\hline
\end{tabular}

\begin{tabular}{|c|c|c|c|c|c|c|c|c|}
\hline \multirow{2}{*}{ Ident. } & $\mathrm{Zn}$ & $\mathrm{Fe}$ & $\mathrm{Mn}$ & $\mathrm{Cu}$ & $\mathrm{B}$ & $\mathrm{Cl}$ & \multirow{2}{*}{$\begin{array}{c}\mathrm{pH} \\
\mathrm{H}_{2} \mathrm{O}\end{array}$} & \multirow{2}{*}{$\begin{array}{c}\mathrm{Na} \\
\%\end{array}$} \\
\hline & \multicolumn{6}{|c|}{ 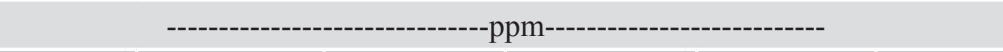 } & & \\
\hline $\mathrm{CB}$ & 546 & 4724 & 501 & 67 & 50.7 & 0.30 & 7.37 & 0.280 \\
\hline $\mathrm{HP}_{\mathrm{HT}}$ & 43 & 16460 & 217 & 22 & 14.7 & 0.10 & 5.84 & 0.008 \\
\hline RHB & 315 & 2050 & 523 & 2 & 4.0 & 0.10 & 7.15 & 0.004 \\
\hline $\mathrm{VC}$ & 93 & 35625 & 496 & 31 & 1.3 & 0.20 & 9.32 & 0.014 \\
\hline SWB & 58 & 16758 & 1103 & 20 & 19.1 & 0.10 & 8.14 & 0.030 \\
\hline EH & 199 & 15718 & 1120 & 32 & 16.9 & 0.30 & 7.59 & 0.022 \\
\hline CSP & 96 & 4813 & 91 & 82 & 39.8 & 0.10 & 6.08 & 0.013 \\
\hline $\mathrm{CM}$ & 141 & 19134 & 691 & 29 & 19.1 & 0.40 & 8.60 & 0.071 \\
\hline
\end{tabular}

$\mathrm{CB}=$ chicken bedding; $\mathrm{HP}_{\mathrm{HT}}=$ Horticultural Plantmax; $\mathrm{RHB}=$ burnt rice husk ; $\mathrm{VC}=$ vermiculite thin; $\mathrm{SWB}=$ sugarcane waste burnt; $\mathrm{EH}=$ earthworm humus; $\mathrm{CSP}=$ coconut husk powder; $\mathrm{CM}=$ cattle manure.

There were not made corrections of substrates related to $\mathrm{pH}$ and electrical conductivity (EC), so that their characteristics are reflected in the development and appearance of the resulting plants. At 45 days after planting and, thereafter, from 15 to 15 days they were made fertigation with $2 \mathrm{~g} \mathrm{~L}^{-1}$ of mixture with commercially fertilizer known as Peter (15-5-15).

At 160 days after planting were evaluated the following characteristics: the number of shoots and leaves, plant height, fresh mass and leaf dry mass, fresh and dry mass of pseudostem, pseudostem diameter (the budding most developed in the pot). The SPAD measurements were made by chlorophyll meter SPAD-502 Plus that provides readings (units "SPAD") corresponding to the pigment content existing in the leaf.

The leaf area of the largest leaf of the pot calculated by the equation proposed by Pinto (2007) $\mathrm{AF}=168.20$ $-83.69 * \mathrm{~L}+4.52 * \mathrm{~L}^{2}+13.30 * \mathrm{C}$, considering linear measurements the width and length of the analyzed leaf. For determination of the dry mass the plants were dried in an oven at a temperature of $65^{\circ} \mathrm{C}$ to constant weight and then weighed with a precision balance.

The experimental design was completely randomized (CRD) with four replications, each experimental unit consisted of a black plastic pot $5 \mathrm{~kg}$ with a rhizome, totaling 96 experimental units.

The data were submitted to analysis of variance and average compared by Tukey test at 5\% probability.
Total contents determined in the acid extract

(Nitric acid with perchloric acid)

$\mathrm{N}$ - Kjeldahl Method

$\mathrm{CO}$ - Walkley Method - Black

Statistical analysis was performed using Statistical Analysis System (SAS) 9.0.

\section{RESULTS AND DISCUSSION}

At 160 days after planting the pseudostem diameter characteristics of the largest sprouting, leaf area of the largest leaf of the pot were not significant. Since the characteristics plant height, number of shoots and leaves, dry and fresh mass of pseudostem, dry and fresh mass of the leaf, and SPAD measurement were significant, indicating that the substrates exerted different effects for these characteristics.

The highest average of fresh and dry mass of the leaf and pseudostem, as well as other variables evaluated situated among the treatments that provided better seedlings served to demonstrate the seedling development potential (size, beauty and vigor) and otherwise, when treatments provided lower averages (small seedlings, weak and chlorotic).

According to Leitão (2006), the proper $\mathrm{pH}$ range for the heliconias cultivation is 5.5 to 6.5 and according Bosa et al. (2003), electrical conductivity (EC) suitable for ornamental plants varies from 0.75 to $2 \mathrm{dS} . \mathrm{m}^{-1}$. From the materials used to compose the substrates, subsoil (S) at pH 5.1 had slightly acidity outside the range recommended for helicons (Table 3). As well as, horticultural Plantmax and coconut husk powder at $\mathrm{pH} 5.8$ and 6.1 within the range, respectively. The remaining materials were found with $\mathrm{pH}$ above 
the recommended range with up to two units (Table 4), however, it appears that plants heliconias are quite tolerant of these variations, because manure and humus, materials that promote the best averages presented their $\mathrm{pH}$ alkaline. Electric conductivity elevated values for chicken bedding increased salinity levels making the means unsuitable for the rhizomes of Heliconia psittacorum.

For leaves number the treatment one (1) gave the highest average, however, fourteen other treatments $(2,14$, $16,5,7,6,20,22,10,21,824,17$ and 4) did not differ statistically from the first, and therefore have the potential to be used in the seedlings production.

Treatment 1 provided highest number of shoots in the rhizome, but did not differ from other twelve treatments $(16,2,7,14,5,8,6,21,20,10,23$ and 17), which also have potential for use in the seedlings production. The other treatments were inferior and did not differ between themselves. The sprouting variation in heliconia is influenced by genetic characteristics, but can be influenced by culture conditions such as the environment and the substrate (GEERTSEN, 1989), availability of water and nutrients. Supposing the climatic conditions were appropriate during cultivation (spring and summer of 2009), it can be concluded that the treatments $(1,16,2,7,14,5$, $8,6,21,20,10,23$ and 17) provided better conditions for sprouting rhizomes, is the adequate availability of nutrients or appropriate water retention (Table 2) or a combination of both factors.

Regarding the quantification of chlorophyll, treatments
8 and 1 were more efficient with SPAD measurements of 67 and 66.8, respectively, did not differ from other 14 treatments (Table 5) which also provide the same measurements.

Eight treatments $(6,23,15,4,11,3,12$ and 9) produced plants with yellowish coloring, and, consequently, smaller SPAD measurements. Although in the review for this work has not been found standard SPAD measurements for helicons plants, it observed that not always a high measurement indicates healthy plants. Some nutritional deficiencies, such as phosphorus for example, which cause reduced growth in young plants and a dark green color of the leaves (TAIZ and ZEIGER, 2004), can provide high measurements and the plant not be healthy. For reasons like this, just SPAD measurement should not be constituted in definitive information.

The plant height had in the treatment seven (7) the highest average, which did not differ by Tukey test at $5 \%$ probability of another eighteen treatments $(13,20,8,2$, $1,5,22,6,10,17,14,4,18,21,16,24,23$ and 15), this variable being negatively affected only for five treatments $(11,3,19,12,9)$ which were not statistically different between themselves.

For leaf fresh mass the treatment one (1) provided the highest average, but did not differ statistically from other ten treatments $(7,5,2,16,22,10,14,8,24$ and 21). Also for this variable, 20 treatments did not differ between themselves (Table 5), which leads to conclude the versatility of the species in the use of different substrates. 
Table 5: Number of leaves, shoot, SPAD measurements and plant height of Heliconia psittacorum seedling grown on different substrate compositions.

\begin{tabular}{|c|c|c|c|c|c|c|c|c|c|}
\hline \multirow{2}{*}{$\begin{array}{c}\text { Number } \\
1\end{array}$} & \multirow{2}{*}{$\begin{array}{l}\text { Treatment * } \\
2 / 3 \mathrm{CM}+1 / 3 \mathrm{CSP}\end{array}$} & \multicolumn{2}{|c|}{ Number of Leaves } & \multicolumn{2}{|c|}{ Number of shoots } & \multicolumn{2}{|c|}{$\begin{array}{c}\text { SPAD } \\
\text { measurements }\end{array}$} & \multicolumn{2}{|c|}{ Plant height } \\
\hline & & 27.50 & $A^{*}$ & 7.25 & A & 66.80 & A & 56.50 & $\mathrm{ABCD}$ \\
\hline 2 & $2 / 3 \mathrm{CM}+1 / 3 \mathrm{RHB}$ & 20.00 & $\mathrm{AB}$ & 5.00 & $\mathrm{AB}$ & 61.28 & $\mathrm{AB}$ & 58.75 & $\mathrm{ABC}$ \\
\hline 3 & $2 / 3 \mathrm{CB}+1 / 3 \mathrm{SWB}$ & 11.00 & B & 2.50 & B & 7.25 & $\mathrm{~F}$ & 36.75 & CDEF \\
\hline 4 & CSP & 13.50 & $\mathrm{AB}$ & 3.25 & B & 20.00 & DEF & 53.00 & $\mathrm{ABCD}$ \\
\hline 5 & $1 / 2 \mathrm{VC}+1 / 2 \mathrm{SWB}$ & 18.00 & $\mathrm{AB}$ & 4.50 & $\mathrm{AB}$ & 60.33 & $\mathrm{AB}$ & 56.00 & $\mathrm{ABCD}$ \\
\hline 6 & $2 / 3 \mathrm{~S}+1 / 3 \mathrm{CB}$ & 16.75 & $\mathrm{AB}$ & 4.50 & $\mathrm{AB}$ & 39.00 & $\mathrm{BCDE}$ & 54.50 & $\mathrm{ABCD}$ \\
\hline 7 & $1 / 3 \mathrm{CM}+2 / 3 \mathrm{SWB}$ & 17.50 & $\mathrm{AB}$ & 4.75 & $\mathrm{AB}$ & 65.28 & $\mathrm{AB}$ & 65.25 & A \\
\hline 8 & $2 / 3 \mathrm{CM}+1 / 3 \mathrm{SWB}$ & 14.50 & $\mathrm{AB}$ & 4.50 & $\mathrm{AB}$ & 67.00 & A & 59.75 & $\mathrm{AB}$ \\
\hline 9 & $2 / 3 \mathrm{CB}+1 / 3 \mathrm{RHB}$ & 10.25 & B & 2.75 & B & 3.13 & $\mathrm{~F}$ & 18.75 & $\mathrm{~F}$ \\
\hline 10 & $1 / 3 \mathrm{CM}+2 / 3 \mathrm{RHB}$ & 15.25 & $\mathrm{AB}$ & 4.00 & $\mathrm{AB}$ & 63.95 & $\mathrm{AB}$ & 54.25 & $\mathrm{ABCD}$ \\
\hline 11 & $1 / 3 \mathrm{CB}+2 / 3 \mathrm{SWB}$ & 13.25 & B & 3.00 & B & 17.63 & $\mathrm{EF}$ & 42.25 & $\mathrm{BCDE}$ \\
\hline 12 & $2 / 3 \mathrm{CB}+1 / 3 \mathrm{CSP}$ & 11.00 & B & 2.25 & B & 6.25 & $\mathrm{~F}$ & 26.50 & $\mathrm{EF}$ \\
\hline 13 & $2 / 3 \mathrm{EH}+1 / 3 \mathrm{CSP}$ & 12.75 & B & 2.50 & B & 49.00 & $\mathrm{ABC}$ & 61.75 & $\mathrm{AB}$ \\
\hline 14 & $2 / 3 \mathrm{EH}+1 / 3 \mathrm{SWB}$ & 18.75 & $\mathrm{AB}$ & 4.75 & $\mathrm{AB}$ & 58.80 & $\mathrm{AB}$ & 53.25 & $\mathrm{ABCD}$ \\
\hline 15 & $1 / 3 \mathrm{CB}+2 / 3 \mathrm{RHB}$ & 12.75 & B & 3.25 & B & 24.00 & $\mathrm{CDEF}$ & 44.25 & $\mathrm{ABCDE}$ \\
\hline 16 & $1 / 3 \mathrm{EH}+2 / 3 \mathrm{SWB}$ & 18.50 & $\mathrm{AB}$ & 5.25 & $\mathrm{AB}$ & 61.13 & $\mathrm{AB}$ & 48.25 & $\mathrm{ABCDE}$ \\
\hline 17 & $2 / 3 \mathrm{EH}+1 / 3 \mathrm{RHB}$ & 13.50 & $\mathrm{AB}$ & 3.75 & $\mathrm{AB}$ & 59.13 & $\mathrm{AB}$ & 53.25 & $\mathrm{ABCD}$ \\
\hline 18 & $1 / 2 \mathrm{VC}+1 / 2 \mathrm{RHB}$ & 11.75 & B & 2.75 & B & 47.65 & $\mathrm{ABC}$ & 49.75 & $\mathrm{ABCD}$ \\
\hline 19 & S & 10.50 & B & 2.75 & B & 58.63 & $\mathrm{AB}$ & 34.50 & DEF \\
\hline 20 & $2 / 3 \mathrm{~S}+1 / 3 \mathrm{CM}$ & 15.75 & $\mathrm{AB}$ & 4.00 & $\mathrm{AB}$ & 64.03 & $\mathrm{AB}$ & 61.25 & $\mathrm{AB}$ \\
\hline 21 & $2 / 3 \mathrm{~S}+1 / 3 \mathrm{EH}$ & 14.50 & $\mathrm{AB}$ & 4.25 & $\mathrm{AB}$ & 64.80 & $\mathrm{AB}$ & 48.25 & $\mathrm{ABCDE}$ \\
\hline 22 & $\mathrm{EH}$ & 15.75 & $\mathrm{AB}$ & 3.50 & B & 61.95 & $\mathrm{AB}$ & 55.50 & $\mathrm{ABCD}$ \\
\hline 23 & HP & 10.50 & B & 3.75 & $\mathrm{AB}$ & 29.53 & CDEF & 44.75 & $\mathrm{ABCDE}$ \\
\hline 24 & $1 / 3 \mathrm{EH}+2 / 3 \mathrm{RHB}$ & 14.00 & $\mathrm{AB}$ & 3.25 & B & 45.00 & $\mathrm{ABCD}$ & 46.75 & $\mathrm{ABCDE}$ \\
\hline $\mathbf{S}$ & & 5.30 & & 1.33 & & 10.10 & & 8.24 & \\
\hline CV\% & & 35.58 & & 34.58 & & 22.00 & & 16.70 & \\
\hline
\end{tabular}

$\mathrm{CM}=$ cattle manure; $\mathrm{CSP}=$ coconut husk powder; $\mathrm{VC}=$ vermiculite $\mathrm{CB}=$ chicken bedding; $\mathrm{SWB}=$ sugarcane waste burnt; RHB = burnt rice husk ; HP = Horticultural Plantmax; $\mathrm{EH}=$ earthworm humus; $\mathrm{S}=$ subsoil.

*Averages followed by the same letter do not differ at the level of 5\% in the Tukey test

For leaf dry mass the treatment one (1) had the highest average, following fresh mass. For pseudostem fresh mass the treatment one (1) presented highest average, but did not differ from other nine treatments $(7,5,2,22,10,14,8$, 16 and 13). For pseudostem dry mass, the treatment one (1) gave the highest average that statistically did not differ from other nine treatments $(7,22,5,10,20,21,2,17$ and $13)$.

Of the eight characteristics that were significant shown in Tables 5 and 6 , the treatment $1(2 / 3 \mathrm{CM}+1 / 3 \mathrm{CSP})$ provided the best averages for the characteristics evaluated in all treatments providing strong indication of being the most suitable for the seedlings production of this heliconias variety.

Plant development is directly affected by the salinity of soil or substrate (AYERS and WESTCOT, 1999), as the higher salinity lower plant development, due to osmotic potential generated by the presence of salts in the soil. In the literature, some authors point chicken bedding as a good material for seedlings production (TEIXEIRA et 
al., 2000), which was not observed in this study, the eight characteristics that were significant, the compositions with chicken bedding always appear between the worst averages, probably because of high EC presented by treatments that had this material, as shown in Table 1. According to Houle et al. (2001) salinity reduces the water potential of the substrate and therefore restricts uptake of water and nutrients; the high electrical conductivity of the resulting salts can cause imbalance and toxicity to plants. Also according to these authors, it appears that these influences can be affected by the sensitivity or development stages of plants. The uptake of salts by plants causes edges and apexes of the leaves, regions where occurs the accumulation of salts absorbed from damage (Figure 2).

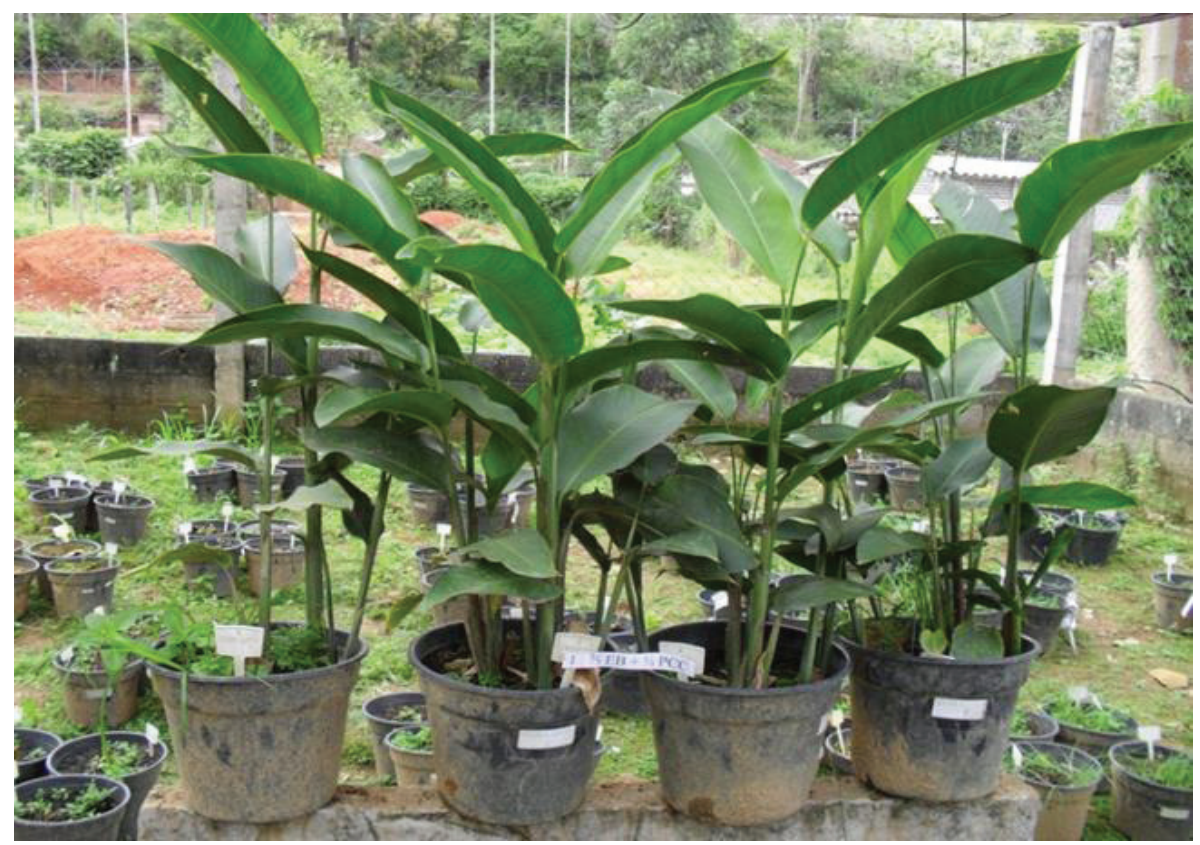

Figure 1. Heliconia psittacorum plants to 160 days after planting the first treatment $(2 / 3$ cattle manure $+1 / 3$ coconut husk powder $)$

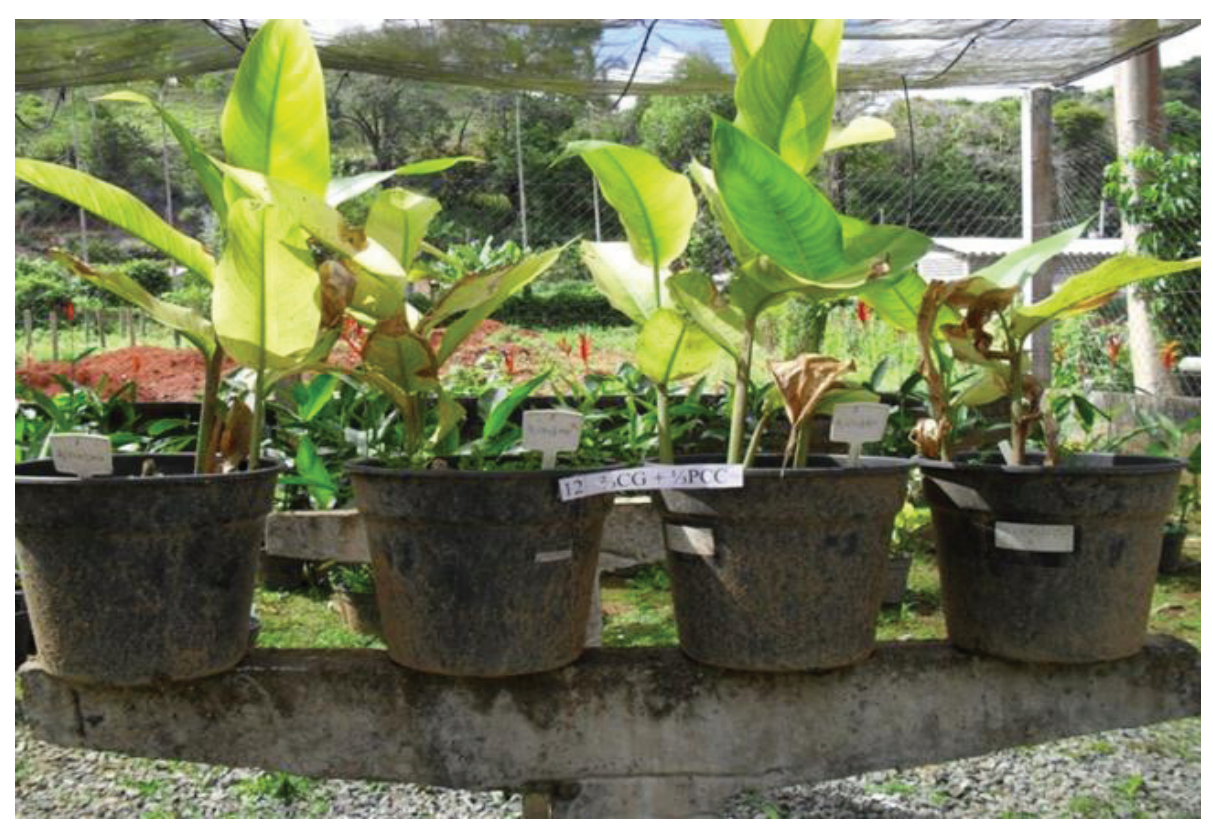

Figure 2. Heliconia psittacorum plants to 160 days after planting of treatment 12 ( $2 / 3$ of chicken bedding $+1 / 3$ coconut husk powder)

On the other hand the treatments that have composition of cattle manure (Figure 1) and earthworm humus especially when mixed with coconut husk powder or burnt rice husk were among the top ten averages or did not differ from larger.
The analysis of the treatments $(1,2,5,7,8,10,14,16,20$ and 22) shows that these have porosity between 72.2 and $90.8 \%$ (Table 1), which is around of the value international reference 85\% (De BOODT and VERDONCK, 1972). 
Noting in Table 1, it can be seen that the apparent densities between 10 treatments that produced the highest averages, are between 0.23 to $0.90 \mathrm{~g} / \mathrm{cm}^{3}$, BUNT (1973), considers in general way the densities values between 0.4 and $0.5 \mathrm{~g} /$ $\mathrm{cm}^{3}$ for substrates as ideal for seedlings production. Kämpf (2000) recommend 0.3 to $0.5 \mathrm{~g} / \mathrm{cm}^{3}$ for pots larger than 30 $\mathrm{cm}$ height. Important characteristics such as porosity and density at appropriate levels corroborate the best results of these treatments. Two treatments among the top ten (16 with $0,23 \mathrm{~g} / \mathrm{cm}^{3}$ and 20 with $0,90 \mathrm{~g} / \mathrm{cm}^{3}$ ) were outside the recommended densities ranges and still produced good seedlings. Thus, demonstrating the great species adaptability to different substrates and soils, as observed by the author Lamas (2006).
According to Wendling and Gatto (2002), the welltanned cattle manure used on the substrate formulation contributes greatly to the improvement of the qualities of the same (increasing the water retention capacity and porosity and aggregation of the substrate) in addition to providing essential nutrients to the seedlings. These characteristics explained in the Tables 1, 2 and 4, justify the best performance of the heliconia plant in this substrate, the same being observed for earthworm humus according to Kiehl (1985); Longo (1987) and Aquino et al. (1992), it is rich in microorganisms, has neutral $\mathrm{pH}$, high water retention and slow mineralization, inserting between the materials that provided the best seedlings (Tables 5 and 6).

Table 6: Dry and fresh mass of leaves, fresh mass and dry mass of Heliconia psittacorum pseudostem grown on different substrates.

\begin{tabular}{|c|c|c|c|c|c|c|c|c|c|}
\hline \multirow{2}{*}{$\begin{array}{c}\text { Number } \\
1\end{array}$} & \multirow{2}{*}{$\begin{array}{c}\text { Treatment } \\
2 / 3 \mathrm{CM}+1 / 3 \mathrm{CSP}\end{array}$} & \multicolumn{2}{|c|}{ Leaf fresh mass } & \multicolumn{2}{|c|}{ Leaf dry mass } & \multicolumn{2}{|c|}{$\begin{array}{l}\text { Pseudostem fresh } \\
\text { mass }\end{array}$} & \multicolumn{2}{|c|}{$\begin{array}{l}\text { Pseudostem dry } \\
\text { mass }\end{array}$} \\
\hline & & 116.00 & $A^{*}$ & 39.00 & A & 169.25 & A & 56.50 & A \\
\hline 2 & $2 / 3 \mathrm{CM}+1 / 3 \mathrm{RHB}$ & 77.00 & $\mathrm{ABCD}$ & 22.50 & $\mathrm{AB}$ & 122.75 & $\mathrm{ABC}$ & 29.00 & $\mathrm{ABCDEF}$ \\
\hline 3 & $2 / 3 \mathrm{CB}+1 / 3 \mathrm{SWB}$ & 36.50 & $\mathrm{BCD}$ & 5.00 & B & 38.75 & $\mathrm{DE}$ & 7.50 & $\mathrm{~F}$ \\
\hline 4 & CSP & 53.25 & $\mathrm{BCD}$ & 1250 & $\mathrm{AB}$ & 77.50 & $\mathrm{BCDE}$ & 17.00 & DEF \\
\hline 5 & $1 / 2 \mathrm{VC}+1 / 2 \mathrm{SWB}$ & 83.25 & $\mathrm{ABC}$ & 32.25 & $\mathrm{AB}$ & 132.50 & $\mathrm{AB}$ & 45.25 & $\mathrm{ABCD}$ \\
\hline 6 & $2 / 3 \mathrm{~S}+1 / 3 \mathrm{CB}$ & 57.75 & $\mathrm{BCD}$ & 23.75 & $\mathrm{AB}$ & 81.25 & $\mathrm{BCDE}$ & 19.75 & CDEF \\
\hline 7 & $1 / 3 \mathrm{CM}+2 / 3 \mathrm{SWB}$ & 91.25 & $\mathrm{AB}$ & 31.75 & $\mathrm{AB}$ & 132.50 & $\mathrm{AB}$ & 51.75 & $\mathrm{AB}$ \\
\hline 8 & $2 / 3 \mathrm{CM}+1 / 3 \mathrm{SWB}$ & 66.25 & $\mathrm{ABCD}$ & 31.25 & $\mathrm{AB}$ & 102.75 & $\mathrm{ABCD}$ & 25.00 & BCDEF \\
\hline 9 & $2 / 3 \mathrm{CB}+1 / 3 \mathrm{RHB}$ & 32.50 & $\mathrm{CD}$ & 4.75 & B & 35.75 & $\mathrm{DE}$ & 3.00 & $\mathrm{~F}$ \\
\hline 10 & $1 / 3 \mathrm{CM}+2 / 3 \mathrm{RHB}$ & 73.75 & $\mathrm{ABCD}$ & 32.00 & $\mathrm{AB}$ & 117.75 & $\mathrm{ABC}$ & 41.50 & $\mathrm{ABCDE}$ \\
\hline 11 & $1 / 3 \mathrm{CB}+2 / 3 \mathrm{SWB}$ & 49.00 & $\mathrm{BCD}$ & 14.75 & $\mathrm{AB}$ & 58.00 & $\mathrm{BCDE}$ & 12.25 & $\mathrm{~F}$ \\
\hline 12 & $2 / 3 \mathrm{CB}+1 / 3 \mathrm{CSP}$ & 27.00 & D & 8.00 & B & 23.75 & E & 5.50 & $\mathrm{~F}$ \\
\hline 13 & $2 / 3 \mathrm{EH}+1 / 3 \mathrm{CSP}$ & 58.25 & $\mathrm{BCD}$ & 20.50 & $\mathrm{AB}$ & 92.75 & $\mathrm{ABCDE}$ & 27.75 & ABCDEF \\
\hline 14 & $2 / 3 \mathrm{EH}+1 / 3 \mathrm{SWB}$ & 69.75 & $\mathrm{ABCD}$ & 24.25 & $\mathrm{AB}$ & 105.00 & $\mathrm{ABCD}$ & 15.25 & $\mathrm{EF}$ \\
\hline 15 & $1 / 3 \mathrm{CB}+2 / 3 \mathrm{RHB}$ & 53.25 & $\mathrm{BCD}$ & 8.50 & B & 64.00 & $\mathrm{BCDE}$ & 5.00 & $\mathrm{~F}$ \\
\hline 16 & $1 / 3 \mathrm{EH}+2 / 3 \mathrm{SWB}$ & 75.00 & $\mathrm{ABCD}$ & 31.25 & $\mathrm{AB}$ & 98.25 & $\mathrm{ABCE}$ & 23.00 & BCDEF \\
\hline 17 & $2 / 3 \mathrm{EH}+1 / 3 \mathrm{RHB}$ & 40.25 & $\mathrm{BCD}$ & 19.25 & $\mathrm{AB}$ & 74.75 & $\mathrm{BCDE}$ & 29.00 & $\mathrm{ABCDEF}$ \\
\hline 18 & $1 / 2 \mathrm{VC}+1 / 2 \mathrm{RHB}$ & 55.75 & $\mathrm{BCD}$ & 23.25 & $\mathrm{AB}$ & 85.00 & $\mathrm{BCDE}$ & 19.00 & DEF \\
\hline 19 & S & 40.75 & $\mathrm{BCD}$ & 6.75 & $\mathrm{~B}$ & 51.75 & $\mathrm{CDE}$ & 6.25 & $\mathrm{~F}$ \\
\hline 20 & $2 / 3 \mathrm{~S}+1 / 3 \mathrm{CM}$ & 50.75 & $\mathrm{BCD}$ & 20.50 & $\mathrm{AB}$ & 83.25 & $\mathrm{BCDE}$ & 29.50 & $\mathrm{ABCDEF}$ \\
\hline 21 & $2 / 3 \mathrm{~S}+1 / 3 \mathrm{EH}$ & 64.00 & $\mathrm{ABCD}$ & 23.75 & $\mathrm{AB}$ & 83.25 & $\mathrm{BCDE}$ & 29.25 & ABCDEF \\
\hline 22 & $\mathrm{EH}$ & 73.75 & $\mathrm{ABCD}$ & 30.50 & $\mathrm{AB}$ & 122.25 & $\mathrm{ABC}$ & 48.75 & $\mathrm{ABC}$ \\
\hline 23 & HP & 3050 & $\mathrm{CD}$ & 6.00 & $\mathrm{~B}$ & 53.75 & $\mathrm{CDE}$ & 11.25 & $\mathrm{~F}$ \\
\hline 24 & $1 / 3 \mathrm{EH}+2 / 3 \mathrm{RHB}$ & 64.75 & $\mathrm{ABCD}$ & 12.75 & $\mathrm{AB}$ & 81.50 & $\mathrm{BCD}$ & 13.25 & $\mathrm{EF}$ \\
\hline $\mathrm{S}$ & & 20.99 & & 10.6 & & 28.83 & & 10.92 & \\
\hline $\mathrm{CV} \%$ & & 34.97 & & 52 & & 33.15 & & 45.86 & \\
\hline
\end{tabular}

$\mathrm{CM}=$ cattle manure; $\mathrm{CSP}=$ coconut husk powder; $\mathrm{VC}=$ vermiculite $\mathrm{CB}=$ chicken bedding; $\mathrm{SWB}=$ sugarcane waste burnt; RHB = burnt rice husk; HP = Horticultural Plantmax; $\mathrm{EH}=$ earthworm humus; $\mathrm{S}=$ subsoil

*Averages followed by the same letter do not differ at the level of $5 \%$ in the Tukey test 
The coconut husk powder is a highly porous material, and therefore, have low density and good drainage capacity (FERMINO and KÄMPF, 2012), while the rice husk have low density and low water retention capacity, good aeration and high macropores percentage which allows faster and more efficient drainage (BARROSO et al., 2010). These two sub-products are considered practically inert substrates, but which when mixed with cattle manure and earthworm humus in minor proportions as seen in Tables 5 and 6 guaranteed the obtaining the best seedlings. The rice husk use and coconut husk powder is of great use because the waste recovery of agribusiness in agricultural practices is the solution of economic, social and environmental problems (KÄMPF, 2000; SILVEIRA et al., 2002). As not have the essential nutrients to plants, they should be used in combination with fertilizers (CARRIJO et al., 2002).

\section{CONCLUSIONS}

Cattle manure and earthworm humus mixed with burnt rice husk and coconut husk powder was the best substrate for the production of Heliconia psittacorum seedlings cultivar 'Andromeda'.

The chicken bedding was the worst, due to high electrical conductivity.

\section{REFERENCES}

AQUINO, A.M.; ALMEIDA, D.L.; SILVA, V.F. Utilização de minhocas na estabilização de resíduos orgânicos: vermicompostagem. Rio de Janeiro: Embrapa-CNPBS, 1992. 12p. (Comunicado Técnico, 8).

AYERS, R.S.; WESTCOT, D.W. A qualidade da água na agricultura. Campina Grande: UFPB, 1999. 218p.

BARROSO, C.M; FRANKE, L.B; BARROS, I.B.I. Substrato e luz na germinação das sementes de rainha-doabismo. Horticultura Brasileira, v.28, n.2, p.236-240, 2010 .

BEZERRA, F.C.; ROSA, M.F.; BRÍGIDO, A.K.L.; NORÕES, E.R.V. Utilização de pó de coco como substrato de enraizamento para estacas de crisântemo. Revista Brasileira de Horticultura Ornamental, v.7, n.2, p.129134. 2001.

BOSA, N.; CALVETE, E.O.; KLEIN, V.A.; SUZIN, M. Crescimento de mudas de gipsofila em diferentes substratos. Revista Brasileira de Horticultura Ornamental, v.21, n.3, p.514-519, 2003.

BUNT, A.C. Some physical and chemical characteristcs of loamless pot-plant substrates and their relation to plant growth. Plant and Soil, n.38, p.1954-1965, 1973.

CARRIJO, O.A.; LIZ, R.S.; MAKISHIMA, N. Fibra da casca do coco verde como substrato agrícola. Horticultura Brasileira, v.20, p.533-535, 2002.
CASTRO, C.E.F.; MAY, A.; GONÇALVES, C. Espécies de helicônia como flores de corte. Revista Brasileira de Horticultura Ornamental, v.12, n.2, p. 87-96, 2006.

De BOODT, M., VERDONCK, O. The physical properties of the substrates in horticulture. Acta Horticulturae, n.26, p.37-44. 1972.

FERMINO, M.H; KÄMPF A.N. Densidade de substratos dependendo dos métodos de análise e níveis de umidade. Horticultura Brasileira, v.30, n.1, p.75-79, 2012.

GEERTSEN V. Influence of photoperiod and temperature on the growth and flower production of Heliconia psittacorum 'Tay'. Acta Horticulturae, n.252, 117-122, 1989.

HOULE, G.; MOREL, L.; REYNOLDS, C.E.; SIEGEL, J. The effect of salinity on different developmental stages of an endemic annual plant, Aster laurentianus (asteraceae). American Journal of Botany, v.88, n.1, p.62-67, 2001.

KÄMPF, A.N. Seleção de materiais para uso como substrato. In: KÄMPF, A.N.; FERMINO, M.H. (Eds.) Substrato para plantas: a base de produção vegetal em recipientes. Porto Alegre: Gênesis, p. 139-145, 2000.

KIEHL, E.J. Fertilizantes orgânicos. São Paulo: Agronômica Ceres, 1985. 492p.

LAMAS, A.M. Técnica de cultivo de flores e folhagens tropicais. Fortaleza: Instituto Frutal, 2006.

LEITÃO, A.P.S. Produção de flores tropicais. Holambra: FLORTEC, 2006. 38p.

LONGO, A.D. Minhoca: de fertilizadora do solo a fonte alimentar. São Paulo: Ícone, 1987. 79p.

LUZ, P.B.; ALMEIDA, E.F.A.; PAIVA, P.D.O.; RIBEIRO, T.R. Cultivo de flores tropicais. Informe Agropecuário Floricultura, v.26, n.227, p.62-70, 72, 2005.

MENEZES JUNIOR, O.G.; FERNANDES, H.S. Substratos formulados com vermicomposto e comerciais na produção de couve-flor. Revista Brasileira de Agrociência, v.4, n.3, p. 191-196, 1998.

MEURER, F.M.; BARBOSA, C.; ZONETTI, P.C.; MUNHOZ, R.E.F. avaliação do uso de bagaço de cana-deaçúcar como substrato no cultivo de mudas de orquídeas. SaBios: Revista de Saúde e Biologia, v.3, n.2, p.45-50, 2008.

PINTO, S.A. Heliconia psittacorum L: propagação e adubação na fase inicial de cultivo. Viçosa-MG: Universidade Federal de Viçosa, UFV, 2007. 92p. Dissertação (Mestrado em Fitotecnia). 
ROSA, M.F.; SANTOS, J.S.S.; MONTENEGRO, A.A.T.; ABREU, F.A.P.; ARAÚJO, F.B.S.; NORÕES, E.R. Caracterização do pó da casca de coco verde usado como substrato agrícola. Fortaleza: Embrapa Agroindústria Tropical, 2001. 6p. (Comunicado Técnico, 5).

SCEHITZ, J.A.K.; SOUZA, P.V.D.; KÄMPF, A.N Propriedades químicas e físicas de substratos de origem mineral e orgânica para o cultivo de mudas em recipientes. Ciência Rural, v.32, n.6, p.937-944, 2002.

SILVEIRA, E.B.; RODRIGUES, V.J.L.B.; GOMES, A.M.A.; MARIANO, R.L.R.; MESQUITA, J.C.P. Pó de coco como substrato para produção de mudas de tomateiro. Horticultura Brasileira, v.20, p.211-216, 2002.
SPIER, M.; SILVA, D.S.; SCHÄFER, G.; SOUZA, P.V.D. cultivo de flor-de-mel em substrato de bagaço de cana-deaçúcar. Scientia Agraria, v.10, n.3, p.251-255, 2009.

TAIZ, L.; ZEIGER, E. Fisiologia vegetal. 3.ed. Trad. de E.R. Santarém. Porto Alegre: Artmed, 2004. 719p.

TEIXEIRA, C.F.A.; PAULETTO, E.A.; SILVA, J.B.; PALMEIRA, P.R. Atributos físicos da camada superficial de um solo Argiloso distrófico típico afetado por sistemas de cultivo em plantio direto. Revista Brasileira de Agrociencia, v.6, p.176-180, 2000.

WENDLING, I., GATTO, A., Substrato, adubação e irrigação na produção de mudas. Viçosa-MG: Aprenda Facil, 2002.165p. 